DOI: $10.26418 /$ positron.v11i2.49355

\title{
Identifikasi Jenis Mikroplastik dan Logam Berat di Air Sungai Kapuas Kota Pontianak
}

Didiek Sugandia, Deri Agustiawana, Shafira Viana Febriyantib, Yulius Yudia, Nelly Wahyunia*

aJurusan Kimia, Fakultas Matematika dan Ilmu Pengetahuan Alam Universitas Tanjungpura, Jl. Prof. Dr. H.

Hadari Nawawi, Pontianak, Kalimantan Barat

bJurusan Teknik Lingkungan, Fakultas Teknik Universitas Tanjungpura, Jl. Prof. Dr. H. Hadari Nawawi, Pontianak, Kalimantan Barat

*Email : nellywahyuni@chemistry.untan.ac.id

(Diterima 17 September 2021; Disetujui 6 Desember 2021; Dipublikasikan 29 Desember 2021)

\begin{abstract}
Abstrak
Sungai Kapuas berperan sebagai sarana transportasi, sumber air baku untuk PDAM, tempat rekreasi, hingga menjadi tempat pembuangan sampah dan limbah bagi masyarakat Pontianak, Kalimantan Barat. Sampah plastik merupakan sampah yang paling banyak dihasilkan karena tingginya aktivitas masyarakat. Sampah plastik yang terpapar sinar ultraviolet atau proses lainnya dapat terdekomposisi menjadi mikroplastik ( $5 \mathrm{~mm}-1 \mu \mathrm{m}$ ) yang dapat berdampak negatif bagi ekosistem perairan bahkan manusia. Penelitian ini bertujuan mengidentifikasi jenis polimer dan logam berat pada mikroplastik yang ada di air Sungai Kapuas. Pengambilan sampel pada 6 titik lokasi didasarkan pada outlet pasar, pelabuhan, penyebrangan feri dan industri. Identifikasi kelimpahan, bentuk dan warna dilakukan dengan menggunakan mikroskop, karakterisasi jenis polimer dengan Fourier Transform Infra Red (FTIR) dan logam berat dengan Scanning Electron Microscope-Energy Dispersive X-Ray (SEM-EDX). Hasil penelitian menunjukkan kelimpahan mikroplastik di Sungai Kapuas sebesar 943,3 partikel/L dengan persentase terbesar berbentuk filamen (33\%) dan fragmen (33\%). Karakterisasi gugus fungsi dengan FTIR menunjukkan adanya plastik jenis polietilena (PE) pada serapan $2918 \mathrm{~cm}^{-1}$, polipropilena (PP) pada serapan $2917 \mathrm{~cm}^{-1}$, polistirena (PS) pada serapan $3348 \mathrm{~cm}^{-1}, 2917 \mathrm{~cm}^{-1}, 1397 \mathrm{~cm}^{-1}$, politetraflouoroetilena (PTPE) pada serapan $1030 \mathrm{~cm}^{-1}$ dan poliamida pada serapan $1586 \mathrm{~cm}^{-1}$. Berdasarkan analisa SEM-EDX, sampel mikroplastik mengandung unsur $\mathrm{C}, \mathrm{O}, \mathrm{Na}, \mathrm{Al}, \mathrm{Si}, \mathrm{Cl}$, dan $\mathrm{K}$ serta tidak ditemukan logam berat. Variasi bentuk, jenis, dan komposisi unsur-unsur pada sampel mikroplastik disebabkan karena adanya perbedaan aktivitas masyarakat di sekitar Sungai Kapuas Kota Pontianak. Penelitian ini dapat menjadi dasar dalam melakukan kegiatan konservasi dan mitigasi dari dampak polusi mikroplastik di kawasan Sungai Kapuas Kota Pontianak.
\end{abstract}

Kata kunci: FTIR, mikroplastik, SEM-EDX, Sungai Kapuas

\section{Pendahuluan}

Mikroplastik adalah plastik berukuran $5 \mathrm{~mm}$ $1 \mu \mathrm{m}$ yang memiliki dampak negatif bagi ekosistem perairan bahkan manusia [1]. Mikroplastik yang dimakan oleh biota perairan dapat menyebabkan terjadinya kerusakan fungsi organ seperti saluran pencernaan, mengurangi tingkat pertumbuhan, menghambat produksi enzim, dan menurunkan kadar hormon steroid [2]. Selain itu, mikroplastik juga dapat menyerap logam berat (seperti $\mathrm{Hg}, \mathrm{Pb}$, $\mathrm{Cr}, \mathrm{Cu}, \mathrm{Cd}$ dan $\mathrm{Zn}$ ) yang ada di lingkungan sekitarnya [3]. Kemampuan mikroplastik dalam mengadsorpsi logam berat bergantung pada sifat fisik dari mikroplastik tersebut seperti ukuran pori, luas permukaan dan jenis mikroplastik [4]. Mikroplastik dapat terbawa ke lautan oleh angin, aliran sungai, dan adanya kegiatan manusia di perairan ataupun di daerah pesisir seperti aktivitas transportasi laut [5].

Sungai Kapuas merupakan sungai yang memiliki panjang mencapai $1.143 \mathrm{~km}$ dan menjadi sungai terpanjang di Indonesia [6]. Sungai ini memiliki 33 anak sungai dan mengalir melalui wilayah Pontianak, Kubu, Tayan, Meliau, Sanggau, Sekadau, Sintang hingga wilayah Kapuas Hulu. Sepanjang aliran Sungai Kapuas terdapat banyak anak sungai yang alirannya berasal dari pegunungan sehingga mengakibatkan volume air Sungai Kapuas bertambah [7].

Sungai Kapuas telah menjadi jantung bagi kehidupan masyarakat Kalimantan Barat yang bermukim di bantaran sungai. Sungai Kapuas umumnya dimanfaatkan sebagai sarana transportasi air, irigasi untuk pertanian, sumber air 
baku untuk PDAM, tempat rekreasi, hingga menjadi tempat pembuangan sampah dan limbah [8].

Sampah plastik adalah sampah yang paling sering dibuang oleh masyarakat di tepian sungai. Sampah plastik tersebut umumnya berupa botol plastik, kantong plastik, tali jala nelayan, dan gelas plastik yang dapat mengalami perubahan ukuran karena terpapar sinar ultraviolet dan mengalami dekomposisi menjadi mikroplastik $[1,9]$.

Saat ini, masih belum ada informasi mengenai penelitian yang mengkaji tentang mikroplastik di Sungai Kapuas dan dampak negatifnya terhadap masyarakat. Oleh karena itu, pada penelitian ini dilakukan identifikasi jenis mikroplastik di Sungai Kapuas. Penelitian ini dilakukan di kawasan Sungai Kapuas Kota Pontianak sebagai dasar kegiatan konservasi dan mitigasi dari dampak polusi mikroplastik.

\section{Metodologi}

Pengambilan sampel dilakukan pada dua sungai yaitu Sungai Kapuas dan Sungai Landak Kota Pontianak, Kalimantan Barat. Gambar 1 menunjukkan 6 lokasi pengambilan sampel air untuk dianalisis kandungan mikroplastik. Enam titik lokasi ini diambil berdasarkan outlet rumah tangga, pasar, pelabuhan, penyebrangan feri dan industri.

Alat-alat yang digunakan dalam penelitian ini yaitu hot plate, shave shaker, oven, vakum filter, dan timbangan analitik. Jumlah, bentuk dan warna mikroplastik dikarakterisasi dengan mikroskop menggunakan perbesaran 4x10 dan 10x10. Karakterisasi jenis mikroplastik menggunakan FTIR dan logam berat menggunakan SEM-EDX. Bahan yang digunakan dalam penelitian ini adalah natrium klorida $(\mathrm{NaCl})$, asam sulfat $\left(\mathrm{H}_{2} \mathrm{SO}_{4}\right)$, besi sulfat $\left(\mathrm{FeSO}_{4}\right)$, hidrogen peroksida $\left(\mathrm{H}_{2} \mathrm{O}_{2}\right)$, pipa paralon 4 inci dan kain monyl T165.

Tabel 1. Titik pengambilan sampel

\begin{tabular}{|c|c|c|}
\hline No & Lokasi & Titik Koordinat \\
\hline 1 & T1 & $-0^{\circ} 3^{\prime} 40^{\prime \prime} \mathrm{S} 109^{\circ} 22^{\prime} 12^{\prime \prime} \mathrm{E}$ \\
\hline 2 & $\mathrm{~T} 2$ & $-0^{\circ} 1^{\prime} 27^{\prime \prime} \mathrm{S} 109^{\circ} 22^{\prime} 31^{\prime \prime} \mathrm{E}$ \\
\hline 3 & $\mathrm{~T} 3$ & $-0^{\circ} 1^{\prime} 16^{\prime \prime} \mathrm{S} 109^{\circ} 20^{\prime} 53^{\prime \prime} \mathrm{E}$ \\
\hline 4 & $\mathrm{~T} 4$ & $-0^{\circ} 1^{\prime} 60^{\prime \prime} \mathrm{S} 109^{\circ} 20^{\prime} 54^{\prime \prime} \mathrm{E}$ \\
\hline 5 & $\mathrm{~T} 5$ & $-0^{\circ} 1^{\prime} 15^{\prime \prime} \mathrm{S} 109^{\circ} 20^{\prime} 21^{\prime \prime} \mathrm{E}$ \\
\hline 6 & $\mathrm{~T} 6$ & $-0^{\circ} 0^{\prime} 71^{\prime \prime} \mathrm{S} 109^{\circ} 17^{\prime} 55^{\prime \prime} \mathrm{E}$ \\
\hline
\end{tabular}

Metode pengambilan hingga preparasi sampel dilakukan dengan mengacu pada penelitian [10]. Proses identifikasi sampel dilakukan dengan berbagai macam prosedur mulai dari pemisahan sampel berdasarkan ukuran $(1 \mathrm{~mm}, 3 \mathrm{~mm}$ dan 45 $\mu \mathrm{m})$, penghancuran bahan organik serta pemisahan densitas. Hasil akhir sampel ini kemudian dikarakterisasi menggunakan mikroskop untuk melihat keberadaan bentuk, jumlah dan warna dari mikroplastik. Analisa gugus fungsi dengan FTIR dan unsur-unsur yang terdapat pada sampel mikroplastik dianalisis dengan menggunakan SEMEDX di Loka Penelitian Teknologi Bersih, Lembaga Ilmu Pengetahuan Indonesia (LIPI), Bandung.

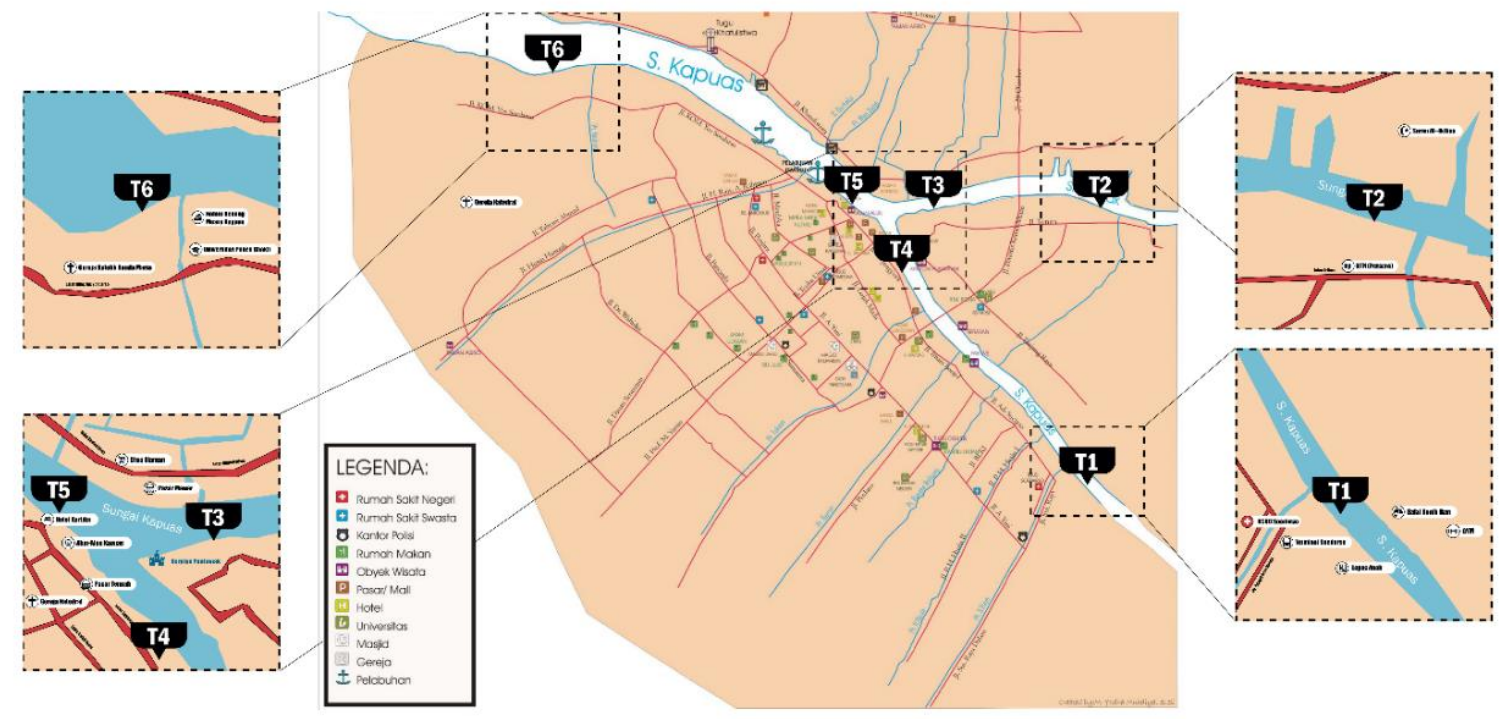

Gambar 1. Lokasi pengambilan sampel air Sungai Kapuas dan Sungai Landak [11] 


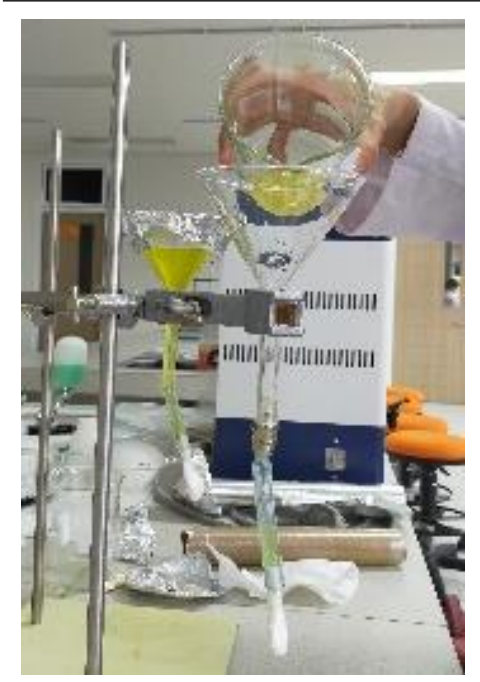

a

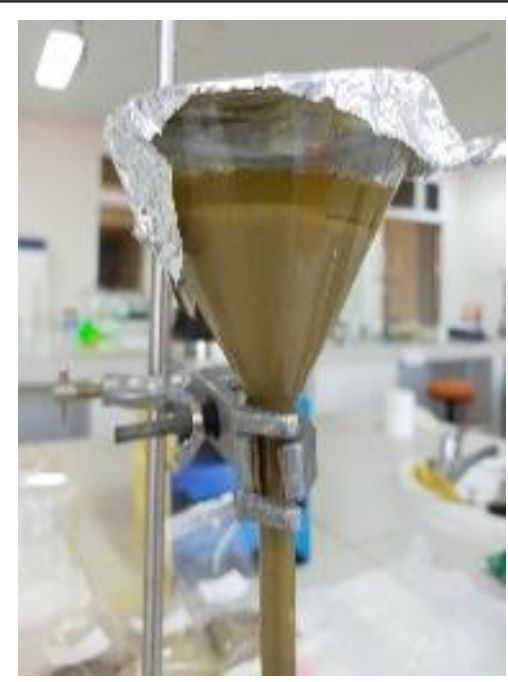

$\mathrm{b}$

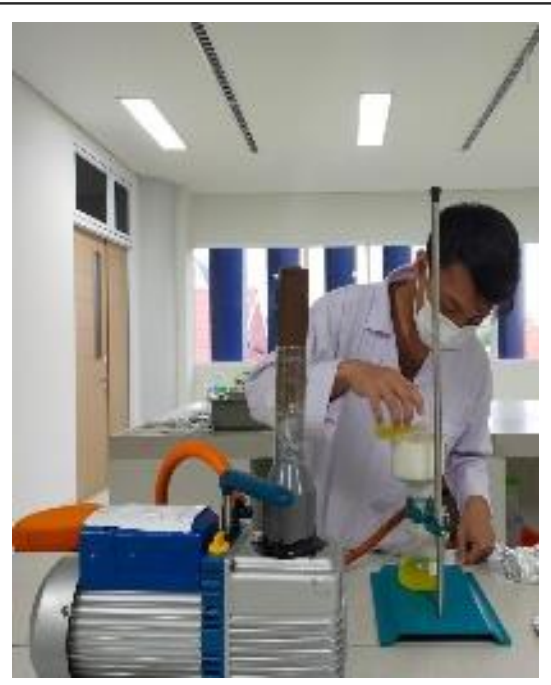

C

Gambar 2. Proses pemisahan densitas: a) sampel dimasukkan dalam corong kaca; b) sampel didiamkan selama 60 menit; c) penyaringan dengan filter vakum

\section{Hasil dan Pembahasan}

Hasil penelitian menunjukkan bahwa plastik yang ditemukan pada sampel air Sungai Kapuas Kota Pontianak berukuran $39 \mu \mathrm{m}-585 \mu \mathrm{m}$. Ukuran ini dikategorikan sebagai mikroplastik karena memiliki ukuran $<1 \mathrm{~mm}$ [1].

Kelimpahan mikroplastik di titik pengambilan sampel air bervariasi (Gambar 3). Pada bagian hulu, yaitu daerah T1 dan T4, adalah Sungai Kapuas kecil dengan jumlah rata-rata mikroplastik 1321 partikel/L. Daerah T2 dan T3 adalah Sungai Landak dengan jumlah rata-rata mikroplastik 690,5 partikel/L, dan pada daerah hilir (T5 dan T6) adalah muara Sungai Kapuas dengan jumlah ratarata mikroplastik 805 partikel/L. Sungai Kapuas kecil dimanfaatkan masyarakat untuk sarana transportasi, pariwisata, perikanan, dan perdagangan. Kegiatan-kegiatan tersebut yang memungkinkan jumlah mikroplastik di Sungai Kapuas dua kali lebih banyak dari Sungai Landak [12].

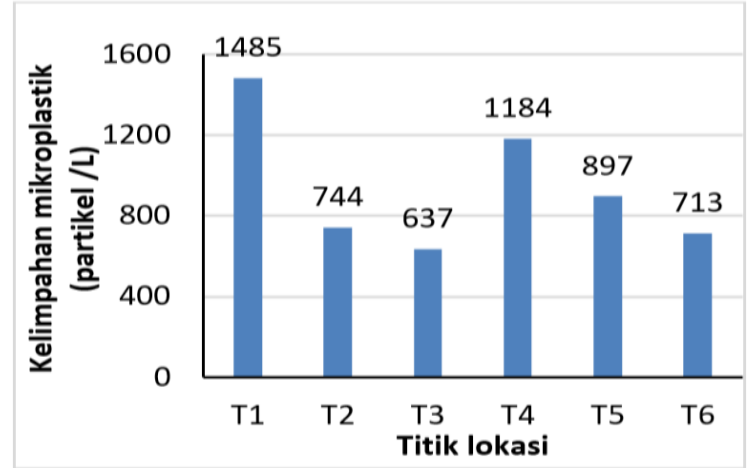

Gambar 3. Kelimpahan mikroplastik di air Sungai Kapuas
Plastikyang terdegradasi menghasilkan bentuk mikroplastik yang beragam (Gambar 4). Bentuk mikroplastik yang didapat saat pengambilan sampel air Sungai Kapuas yaitu fiber, fragmen, pelet, foam, dan filamen. Persentase bentuk mikroplastik berturut-turut yaitu fragmen (33\%), filament (33\%), fiber (19\%), pelet (9\%) dan foam (6\%).

Perbedaan bentuk mikroplastik yang didapat bisa dilihat dari aktivitas masyarakat yang ada di sekitar Sungai Kapuas [10]. Mikroplastik bentuk fragmen dan filamen bersumber dari limbah yang sama yaitu dari aktivitas manusia seperti pembuangan plastik berupa botol, kantong dan gelas plastik sekali pakai yang terdegradasi [13]. Mikroplastik bentuk fragmen dan filamen diduga merupakan polimer plastik polietilena dan polipropilena [14]. Mikroplastik bentuk fiber atau serat diduga berasal dari jaring nelayan atau limbah dari kegiatan pencucian pakaian [15]. Fiber diduga merupakan polimer plastik poliamida [14]. Mikroplastik bentuk pelet diduga berasal dari microbeads yang sengaja dibuat oleh industri untuk produk kecantikan (mikroplastik primer). Pelet diduga merupakan polimer jenis polietilena [16]. Mikroplastik jenis foam berasal dari sterofoam seperti bungkus mie instan yang biasa dikonsumsi dan merupakan polimer jenis polistirena [17].

Warna yang paling banyak ditemukan pada mikroplastik yaitu bening/transparan dengan ratarata 220,16 partikel/L. Warna ini berasal dari plastik asal yang baru terdegradasi serta plastik yang sudah lama terdegradasi dan luntur [18]. Warna mikroplastik yang bervariasi diakibatkan 
karena aktivitas masyarakat di sekitar Sungai Kapuas Kota Pontianak yang mendistribusikan berbagai macam plastik. Warna dan bentuk pada mikroplastik merupakan penelitian awal untuk menduga jenis polimer plastik. Dugaan ini diperkuat dengan analisis FT-IR dan SEM EDX.

Identifikasi jenis polimer mikroplastik pada air dilakukan dengan menggunakan FT-IR yang dapat dilihat pada Gambar 6. Hasil dari analisis FT-IR dikonfirmasi dengan gugus fungsi yang menunjukkan bahwa terdapat beberapa jenis polimer mikroplastik diantaranya yaitu polietilena (PE), polipropilena (PP), polistirena (PS), politetraflouoroetilena (PTPE) dan poliamida. Polimer PE dan PP ditandai dengan adanya puncak serapan pada bilangan gelombang 2935-2915 $\mathrm{cm}^{-1}$ yang merupakan vibrasi $\mathrm{CH}$. $\mathrm{CH}$ merupakan penyusun utama dari polimer jenis PE dan PP [19].

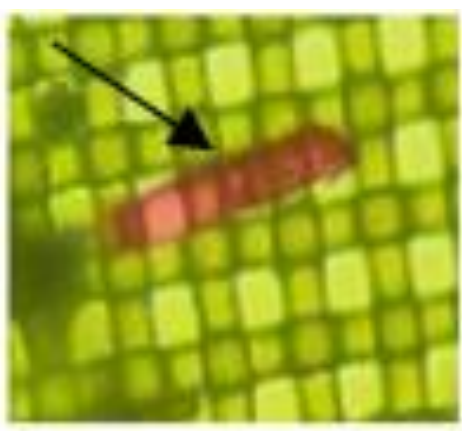

a

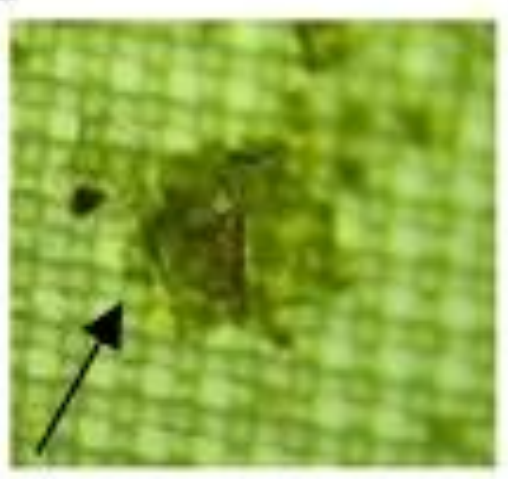

d

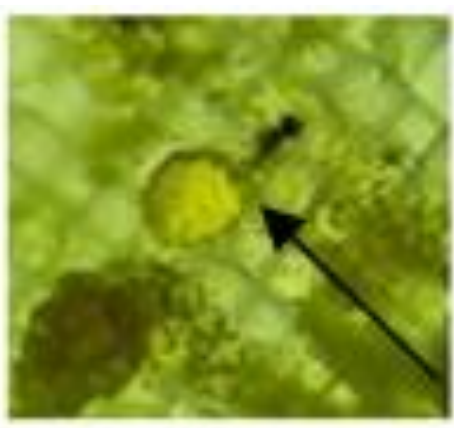

b

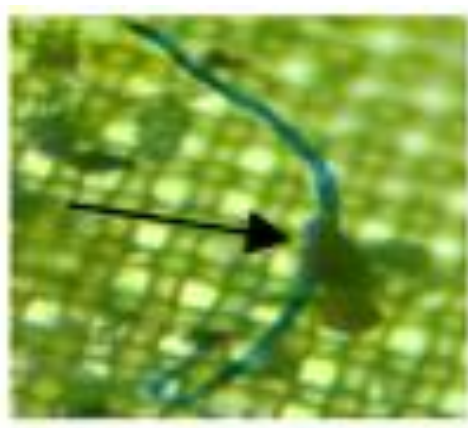

c

Gambar 4. Bentuk mikroplastik Sungai Kapuas: a) fragmen; b) pelet; c) fiber; d) filamen; e) foam

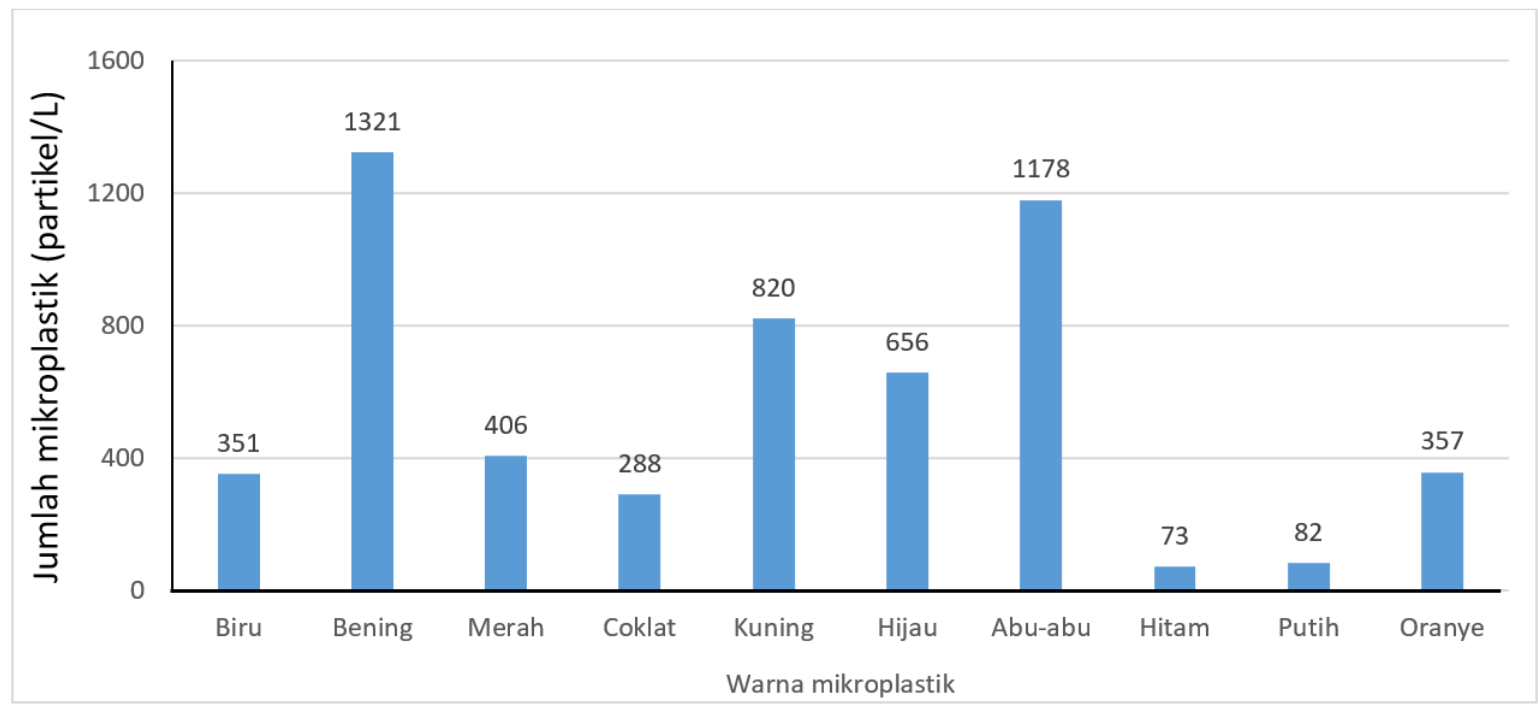

Gambar 5. Warna mikroplastik di air Sungai Kapuas 

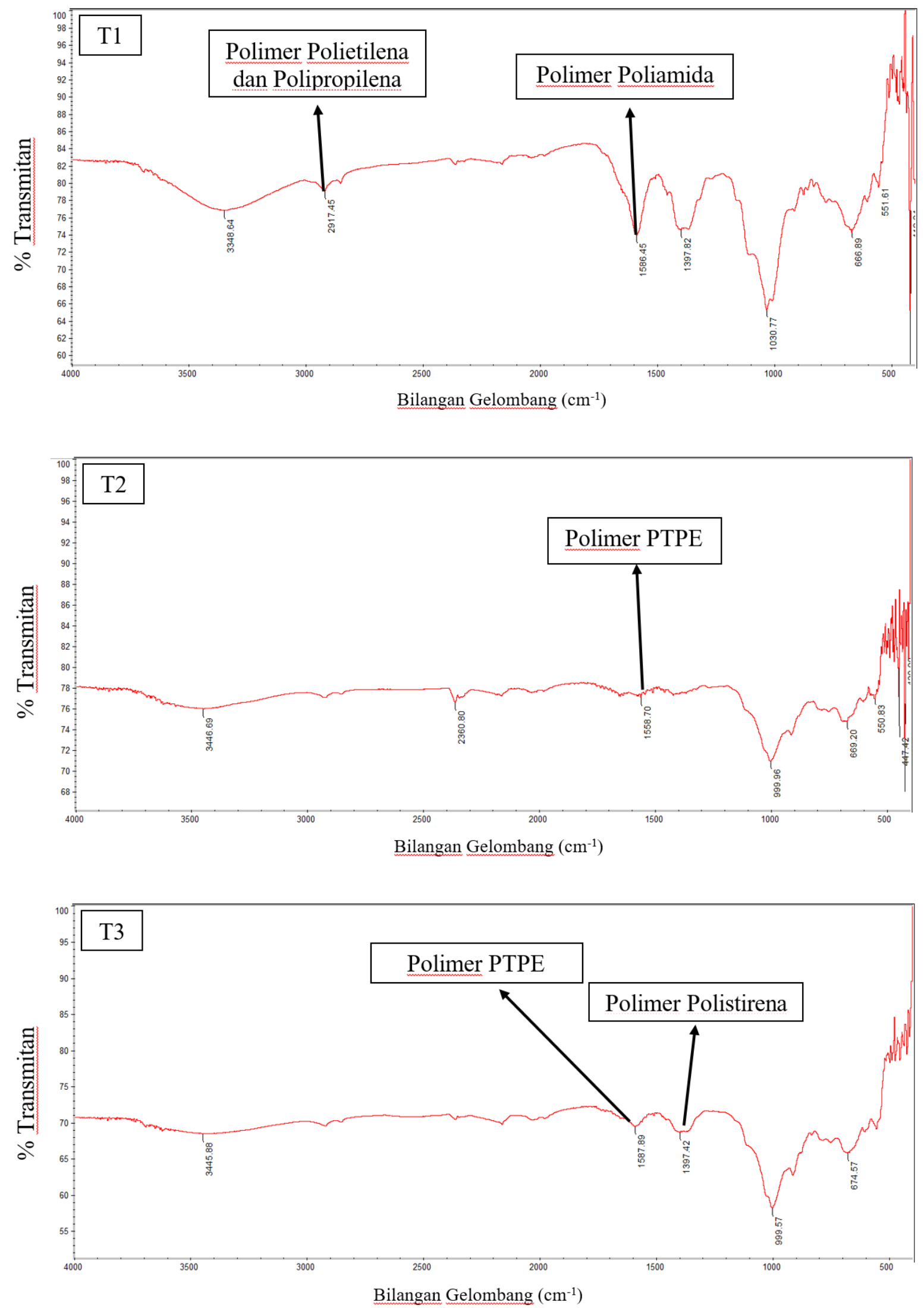

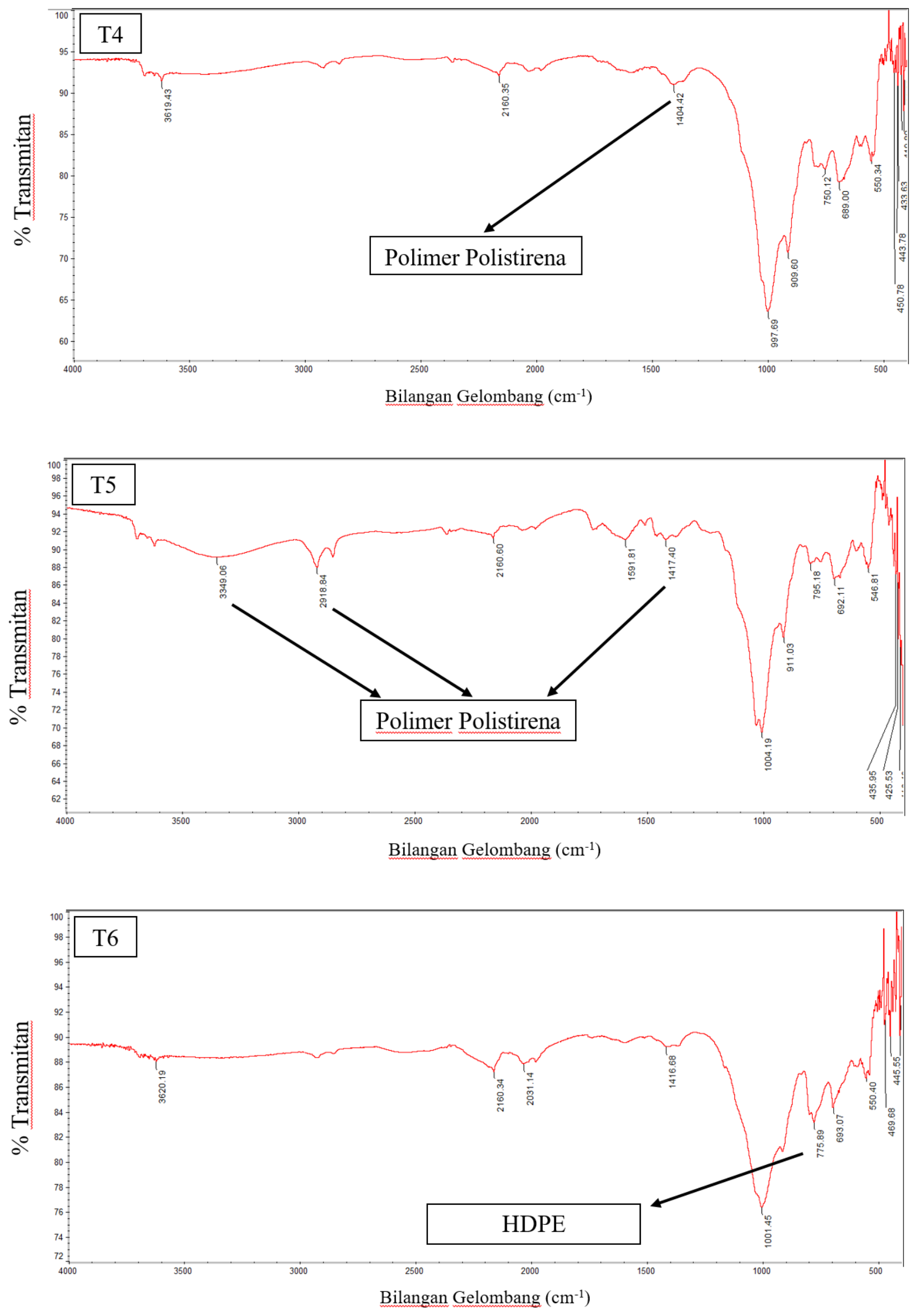

Gambar 6. Spektrum fourier transform infrared pada sampel air yang diambil dari Sungai Kapuas 
Keberadaan polimer poliamida diperkuat dengan munculnya serapan pada $1652 \mathrm{~cm}^{-1}$ dan berada pada rentang $1650-1620 \mathrm{~cm}^{-1}$ yang merupakan daerah vibrasi tekuk $\mathrm{NH}$. Ikatan $\mathrm{NH}$ merupakan ikatan penyusun poliamida atau biasa disebut nylon [20]. Jenis polimer PTPE ditandai dengan adanya serapan C-F pada daerah bilangan gelombang 1150-100 $\mathrm{cm}^{-1}$. PTPE dicirikan dengan adanya serapan pada bilangan gelombang 1155 $\mathrm{cm}^{-1}[21]$.

Plastik jenis polistirena dicirikan dengan adanya gugus fungsi $\mathrm{C}-\mathrm{H}$ phenyl, $\mathrm{CH}$ alifatis, $\mathrm{CH}_{2}$ aromatik dan phenyl yang teridentifikasi pada IR dengan adanya serapan pada $3348 \mathrm{~cm}^{-1}, 2917 \mathrm{~cm}^{-1}$ dan $1397 \mathrm{~cm}^{-1}$. Dugaan ini hampir sama dengan penelitian tentang polistirena murni dengan puncak panjang gelombang 3348,05 $\mathrm{cm}^{-1}, 2918,84$ $\mathrm{cm}^{-1}$ dan $1453,28 \mathrm{~cm}^{-1}$ [22].

Karakterisasi jenis unsur dalam mikroplastik menggunakan metode SEM-EDX ini merupakan penelitian awal yang dapat memberikan informasi tentang jenis-jenis unsur yang terdapat dalam mikroplastik dengan mengetahui kandungan baik kandungan unsur maupun oksidanya. Karakterisasi menggunakan alat SEM-EDX dapat memberikan hasil yang lebih akurat [23].

Analisa pada mikroplastik menggunakan SEMEDX diperoleh hasil berupa persentase unsur penyusun masing-masing yang dapat dilihat pada Tabel 2. Unsur Al dapat berasal dari zat aditif pigmen anorganik dan tahan api, sedangkan $\mathrm{Si}$ merupakan salah satu bahan pengisi pada pembuatan plastik serta pada unsur $O$ dan $C$ merupakan monomer penyusun plastik [24]. Unsur Al dan Si diduga juga berasal dari tanah gambut sehingga teradsorpsi dan terbawa oleh mikroplastik. Unsur lainnya yaitu $\mathrm{Na}$ dan $\mathrm{Cl}$ diduga berasal dari sisa garam $\mathrm{NaCl}$ yang digunakan pada pemisahan densitas mikroplastik.

Tabel 2. Persentase unsur pada sampel mikroplastik berdasarkan analisa SEM-EDX

\begin{tabular}{|c|c|c|}
\hline No & Unsur & Persentase (\%) \\
\hline 1 & $\mathrm{C}$ & 76,66 \\
\hline 2 & 0 & 20,54 \\
\hline 3 & $\mathrm{Na}$ & 1,37 \\
\hline 4 & $\mathrm{Al}$ & 0,15 \\
\hline 5 & $\mathrm{Si}$ & 0,16 \\
\hline 6 & $\mathrm{Cl}$ & 0,92 \\
\hline 7 & $\mathrm{~K}$ & 0,10 \\
\hline \multicolumn{3}{|c|}{ Total } \\
\hline
\end{tabular}

Mikroplastik memiliki dampak negatif bagi kesehatan manusia seperti dapat menyebabkan peradangan pada otak dan stres oksidatif [25-26]. Mikroplastik juga dapat masuk ke rongga usus hingga sistem peredaran darah yang dapat mengganggu sistem pencernaan, menyebabkan kanker, iritasi kulit, penyakit kardiovaskular dan masalah pernapasan hingga masalah reproduksi [25, 27-29].

\section{Kesimpulan}

Mikroplastik yang teridentifikasi dari 6 titik pengambilan sampel air Sungai Kapuas berjumlah 943,3 partikel/L yang ditemukan dalam bentuk fragmen, filamen, fiber, pelet dan foam. Mikroplastik yang dominan ditemukan pada Sungai Kapuas yaitu bentuk filamen (33\%) dan fragmen (33\%). Mikroplastik memiliki warna yang bervariasi, dan yang paling banyak ditemukan adalah transparan atau bening yang berasal dari plastik jenis polipropilena. Jenis mikroplastik yang didapat yaitu polietilena (PE), polipropilena (PP), polistirena (PS), politetraflouoroetilena (PTPE) dan poliamida. Sampel mikroplastik juga mengandung unsur C, O, Na, Al, Si, Cl dan K. Mikroplastik memiliki dampak negatif bagi kesehatan masyarakat diantaranya yaitu dapat menyebabkan peradangan pada otak, meningkatkan stres oksidatif, mengganggu sistem pencernaan, menyebabkan kanker, iritasi kulit, penyakit kardiovaskular dan masalah pernapasan hingga masalah reproduksi pada manusia.

\section{Ucapan Terima Kasih}

Terima kasih penulis sampaikan kepada Direktorat Pembelajaran dan Kemahasiswaan (Belmawa) atas dana yang telah diberikan melalui Program Kreativitas Mahasiswa (PKM). Penulis juga mengucapkan terima kasih kepada Lia Harmelia, S.Si yang telah membantu dan membimbing penulis selama pelaksanaan penelitian.

\section{Daftar Pustaka}

[1] Iwasaki, S., Isobe, A., Kako, S., Uchida, K. dan Tokai, T., Fate of Microplastics and Mesoplastics Carrried by Surface Currents and Wind Waves: A Numerical Model Approach in the Sea of Japan, Marine Pollution Bulletin, 121(1-2), pp. 85-96, 2017.

[2] Wright, S. L., Thompson, R. C. dan Galloway, T. S., The Physical Impacts of Microplastics on 
Marine Organism: a Review, Environmental Pollution, 178, pp. 483-492, 2013.

[3] Rochman, M. C., Browne, A. J., Underwood, J. A. VanFraneker, R. C., Thompson, L. dan Zetteler, A., The Ecological Impacts of Marine Debris: Unraveling The Demonstrated Evidence From What is Perceiveed, Ecology, 97, pp. 302-312, 2015.

[4] Oz, N., Kadizade., G. dan Yurtsever, M., Investigation of Heavy Metal Adsorption on Microplastics, Engineering Faculty, Sakarya University. Turkey, 2019.

[5] Solomon, 0. 0. dan Palanisami, T., Microplastics in the Marine Environment: Current Status, Assessment Methodologies, Impacts and Solutions, Journal of Pollution Effects \& Control, 4(2), pp. 1-13, 2016.

[6] Jumarang, M. I., Muliadi, Ningsih, N. S., Hadi, S. dan Martha, D., Pola Sirkulasi Arus dan Salinitas Perairan Estuari Sungai Kapuas Kalimantan Barat, Positron, 1(1), pp. 36-42, 2011.

[7] Kusnoto, Y. dan Purmintasari, Y. D., Pemukiman Awal Sungai Kapuas, Jurnal IlmuIlmu Sosial, 15(1), pp. 71-78, 2018.

[8] Septiani, E., Setyawati, T. R. dan Yanti, A. H., Kualitas Perairan Sungai Kapuas Kota Sintang Ditinjau dari Keanekaragaman Makrozoobentos, Protobiont, 2(2), pp. 70-74, 2013.

[9] Ismi, H., Amalia, A. R., Sari, N., Gesriantuti, N. dan Badrun, Y., Dampak Mikroplastik terhadap Makrozoobentos; Suatu Ancaman Bagi Biota di Sungai Siak, Pekanbaru, Prosiding Sains TeKes, 1, 2019.

[10] Sugandi, D., Agustiawan, D., Febriyanti, S. V., Yudi, Y. dan Wahyuni, N. (in press), Identifikasi Kelimpahan Mikroplastik di Perairan Sungai Kapuas dan Sungai Landak, Kalimantan Barat, Prosiding Seminar Nasional Sains, Terapan \& Pendidikan Kimia, 2021.

[11] Peta Kota Pontianak, https://petakota.blogspot.com/2011/05/peta-kotapontianak.html (accessed 22 Agustus 2021).

[12] Nurdianti, A. K., Admodjo, W. dan Saputro, S., Studi Batimetri dan Kondisi Alur Pelayaran di Muara Sungai Kapuas Kecil, Kalimantan Barat, Jurnal Oseanografi, 5(4), pp. 530-545, 2016.

[13] Eriksen, M., Mason, S., Wilson, S., Box, C., Zellers, A., Edwards, W., Farley, H. dan Amato, S., Microplastic Pollution in the Surface Waters of the Laurentian Great Lakes, Marine Pollution Bulletin, 77(1-2), pp. 177-182, 2013.

[14] Pawar, P. R., Shirgaonkar, S. S. dan Patil, R. B., Plastic Marine Debris: Sources, Distribution and Impacts on Coastal and Ocean
Biodiversity, Pencil Publication of Biological Sciences, 3(1), pp. 40-54, 2016.

[15] Hanif, K. H., Suprijanto, J. dan Pratikto, I., Identifikasi Mikroplastik di Muara Sungai Kendal, Journal of Marine Research, 10(1), pp. 1-6, 2021.

[16] Lenaker, P. L., Baldwin, A. K., Corsi, S. R., Mason, S. A., Reneau, P. C. dan Scott, J. W., Vertical Distribution of Microplastics in the Water Column and Surficial Sediment from the Milwaukee River Basin to Lake Michigan, Environmental Science and Technology, 53(21), pp. 12227-12237, 2019.

[17] Yin, L., Jiang, C., Wen, X., Du, C., Zhong, W., Feng, Z., Long, Y. dan Ma, Y., Microplastic Pollution in Surface Water of Urban Lakes in Changsha, China, International Journal of Environmental Research and Public Health, 16(1650), pp. 110, 2019.

[18] Ridlo, A., Ario, R., Ayyub, A. M., Supriyantini, E. dan Sedjati, S., Mikroplastik pada Kedalaman Sedimen yang Berbeda di Pantai Ayah Kebumen Jawa Tengah, Jurnal Kelautan Tropis, 23(3), pp. 325-332, 2020.

[19] Syakti, A.D., Microplastics Monitoring in Marine Environment,Omni-Akuatik, 11(2), pp. 1-6, 2017.

[20] Pawar, P. R., Shirgaonkar, S. S. dan Patil, R. B., Plastic Marine Debris: Sources, Distribution and Impacts on Coastal and Ocean Biodiversity, Pencil Publication of Biological Sciences, 3(1), pp. 40-54. 2016.

[21] Piwowarczyk, J., Jędrzejewski, R., Moszyński, D., Kwiatkowski, K., Niemczyk, A., dan Baranowska, J., XPS and FTIR Studies of Polytetrafluoroethylene Thin Films Obtained by Physical Methods, Polymers, 11(10), pp. 113, 2019.

[22] Qodri, F., Karakteristik Komposit Polystirena Termodifikasi Anhidrida Maleat sebagai Pengikat Agregat Pasir, Skripsi, Fakultas Matematika dan Ilmu Pengetahuan Alam, Universitas Sumatera Utara, 2019.

[23] Srivastava, A., dan Vinod K.J., Applying SEMEDX and XRD Techniques to Demonstrate the Overgrowth of Atmospheric Soot and Its Coalescence with Crystal Silicate Particles in Delhi, Atmospheric and Climate Sciences, 2 (1), pp. 89-93, 2012.

[24] Campanale, C., Massarelli, C., Savino, I., Locavuto, V. dan Uricchio, V. F., A Detailed Review Study on Potential Effects of Microplastics and Additives of Concern on Human Health, Journal of Environmental Research and Public Healt, 17(1212), pp. 1-27, 2020. 
[25] Bouwmeester, H., Hollman, P. C. H. dan Peters, R. J. B., Potential Healt Impact of Environmentally Released Micro- and Nanoplastics in the Human Food Production Chain: Experience from Nanotoxicology, Environ Sci Technol, 49(15), pp. 8932-8947, 2015.

[26] Nelms, S. E., Galloway, T. S., Godley, B. J., Jarvis, D. S. dan Lindeque, P. K., Investigating Microplastic Trophic Transfer in Marine Top Predators, Environmental Pollution, 238, pp. 999-1007, 2018.
[27] Yu, Q., Hu, X., Yang, B., Zhang, G. Wang, J. dan Ling, W., Distribution, Abundance and Risks of Microplastic in the Environmental, Chemosphere, 249, pp. 1-2, 2020.

[28] De-La-Torre, G. E., Microplastics: an Emerging Threat to Food Security dan Human Healt, Journal Food Sci Technol, 57(5), pp. 16011608,2020

[29] Smith, M., Love, D. C., Rochman, C. M. dan Neff, R. A., Microplastics in Seafood and the Implication for Human Health, Current Environmental Healt Reports, 5(3), pp. 375386, 2018. 